\title{
TECCIENCIA
}

\section{Machining With Cutting Tool Coated With Monolayer Of HfN}

\author{
Mecanizado Con Herramienta De Corte Recubierta Con Monocapa De HfN
}

\author{
Pablo Andrés Guzmán Durán ${ }^{1 *}$, John Henry Navarro-Devia ${ }^{1}$, Willian Aperador Chaparro ${ }^{1}$, \\ ${ }^{1}$ Universidad Militar Nueva Granada, Bogotá, Colombia
}

\begin{abstract}
In this study, AISI 1020 steel was machined by chip removal, in dry conditions, using ASSAB 17 tool bits with Hafnium Nitride (HfN) monolayer coating, deposited as a thin film via magnetron sputtering physical vapor deposition (PVD) technique, and uncoated tool bits, used as reference system. The surfaces of the machined steel were evaluated and characterized using Atomic Force Microscopy (AFM) and Scanning Electron Microscopy (SEM). The use of monolayer HfN coating on the tool bits was demonstrated to improve the surface finish of the workpiece and reduce cutting process time and cost.
\end{abstract}

Keywords: Monolayer, Surface roughness, Machining, Cutting Tools, Hafnium Nitride.

\section{Resumen}

En este trabajo, se realizó el mecanizado por arranque de viruta del acero AISI 1020, en condiciones de ausencia de lubricación; utilizando buriles de acero rápido ASSAB 17, con recubrimiento monocapa de Nitruro de Hafnio (HfN) depositados como película delgada, mediante la técnica de deposición física en fase vapor (PVD) magnetrón sputtering y con buriles sin recubrir, usados como sistemas de referencias. Posteriormente se evaluaron las superficies obtenidas en el acero mecanizado, caracterizándolas mediante microscopia de fuerza atómica (MFA) y microscopia electrónica de barrido (MEB). Se evidencio que el uso de recubrimientos monocapa de $\mathrm{HfN}$ sobre los buriles de acero rápido, mejoran el acabado superficial del material mecanizado, reduciendo los tiempos y costos del proceso de corte.

Palabras clave: Monocapa, Rugosidad Superficial, Mecanizado, Herramientas de corte, Nitruro de Hafnio.

\section{Introduction}

One of the most important criteria in the machining of metallic materials - in terms of the quality of the process, the geometry and the tolerance of the workpiece - is the surface finish obtained. This is influenced by the parameters of the cut, the properties of the cutting tool, the characteristics of the material to be worked on and the interaction among all these factors [1-3]. In industry, the surface finish of the product is evaluated by estimating the two most important roughness parameters, which are a) the

*Corresponding Author.

E-mail: g.ing.materiales@gmail.com arithmetical mean deviation of the roughness profile $(R a)$ and b) the maximum height of the roughness profile $(R z)[4]$.

Moreover, in industry there is the constant challenge of reducing cutting costs and increasing the quality of the machining of metallic materials. Hence, the ability to machine metals by chip removal is evaluated, through the inspection of tool wear, the cutting forces generated and the surface finish of the workpiece [5-8].

Traditional optical microscopes have been utilized in a variety of fields, but their configuration has limitations.

How to cite: Guzmán, P., Navarro-Devia, J.H., Aperador, W., Machining With A Cutting Tool Coated With A Monolayer Of HfN, TECCIENCIA, Vol. 12 No. 21, 1-6, 2016, DOI: http:/dx.doi.org/ 


\section{TECCIENCLA}

This produces the need for new devices capable of improving the observation of all types of elements, allowing for more detailed analysis of the surface of a material [9-11]. This required the development of new microscopes that permit the observation of materials at a smaller scale, via different methods [12] [13]. Ever since the advent of the transmission electron microscopy, a range of technology has been implemented which has proven helpful in deepening the study of materials and their surfaces [14] [15] [16] [17].

The scanning electron microscope (SEM) has been very important in the observation of objects because it allows greater magnification than optical microscopes and its depth of field provides better observation of the sample, producing a high definition image [18]. With the use of new technologies the study of materials can be further explored. One example is the atomic force microscope (AFM), which allows visual displays on a nanometric scale and analyzes in more detail a sample subjected to different conditions [19] [20]. The importance of analyzing the surface finish and possible deformations of material lies in the characterization of tool operation and the way the material surface is affected. This provides the roughness profile $(R a)$ and the definition of the areas where fatigue or stress are generated by the tool [21] [22].

Nitrides are a crystallographic defect which are interstitial. Nitrogen atoms are introduced in a part of the crystalline structure where atoms are normally not found. This kind of structural modifications has been topic of interest for industrial applications. One example of such nitrides is Hafnium Nitride (HfN) [21]. The electronegativity difference between nitrogen (3.0) and hafnium (1.3), together with the atomic sizes, allow for the rapid diffusion and settlement of the nitrogen atoms in the interstices of the hafnium crystal structure.

In these compounds the bonds are mixed ionic-covalent, with an ionic character of $52 \%$ and a covalent character of $48 \%$ [24], giving the interstitial nitrides characteristics such as high thermal and electrical conductivity. These materials also have a high melting point and high hardness. Furthermore, they are chemically inert and have a refractory nature [25]. The coatings in the form of single layer of hafnium nitride (HfN) have been developed for use in the electronic industry, which explains why there is few literature concerning the mechanical and tribological properties.

The purpose of the present study was to characterize the surface finish that was obtained by cutting with tool bits both coated and uncoated in Hafnium Nitride, using AFM and SEM techniques. The aim was not to evaluate the lifespan of coated tools, but rather to identify, in the different samples, how the coated and uncoated tool affects the final state of the machined material.

\section{Materials and Methods}

\subsection{Coating deposition}

In order to grow thin films of hafnium nitride, a R.F. magnetron sputtering system was used. The equipment consists of a stainless steel chamber, which has a base pressure inside the vacuum chamber of $2.3 \times 10^{-3} \mathrm{mbar}$ and a total working pressure of $3.6 \times 10^{-3}$ mbar. It also has a substrate temperature of $400{ }^{\circ} \mathrm{C}$, an R.F. bias voltage of $70 \mathrm{~V}$ and $400 \mathrm{~W}$ of power. During growth, the working gases were a mixture of $\operatorname{Ar}(93 \%)$ and $\mathrm{N}_{2}(7 \%)$. In the coating deposition process it was used a 4-inch-diameter hafnium target with $99.9 \%$ purity as source material. The tool bits were degreased via ultrasonic washing in ethanol and acetone for 15-minute, and were then admitted to the magnetron for the film growth.

\subsection{Cutting process and Characterization}

The turning process was performed by chip removal in computer numerical control turning center $(\mathrm{CNC})$, under conditions of no lubrication, on AISI 1020 steel rods of 0.5 inches in diameter. The process used a conventional tool without coating, with a spindle rotation speed of $500 \mathrm{rpm}$, a tool feed rate of $0.25 \mathrm{~mm} / \mathrm{rev}$, a diametrical penetration of $2 \mathrm{~mm}$, a rod length of $30 \mathrm{~cm}$ and a cut length of $10 \mathrm{~cm}$.

We subsequently polished the AISI 1020 samples, but this time the tool was used with and without HfN coating. The process involved two different cuts, made sequentially on the machined steel with the previous conventional tool, using the cutting parameters reported in Table 1.

Table 1. Parameters of the polishing process using tools with and without HfN coating.

\begin{tabular}{lll}
\hline \multicolumn{1}{c}{ Parameter } & \multicolumn{1}{c}{ First polish } & \multicolumn{1}{c}{ Second polish } \\
\hline Spindle rotation speed & $500 \mathrm{rpm}$ & $1000 \mathrm{rpm}$ \\
Tool feed rate & $0.08 \mathrm{~mm} / \mathrm{rev}$ & $0.01 \mathrm{~mm} / \mathrm{rev}$ \\
Diametrical penetration & $0.25 \mathrm{~mm}$ & $0.10 \mathrm{~mm}$ \\
Tool speed & $40 \mathrm{~mm} / \mathrm{min}$ & $10 \mathrm{~mm} / \mathrm{min}$ \\
\hline
\end{tabular}

In order to measure the surfaces of the materials and to identify the degree of irregularity in the polish, we used a PCE-RT 1200 roughness tester. This device detects surface roughness by employing a diamond probe pin that moves along a given length of the material. We determined the numerical value of the roughness according to the normalization rules, which this type of measurement system 


\section{TECCIENCLA}

is subjected to, defined as $R a$ [4] [26].

The characterization of the surface finish in function of the type of tool bit used in the AISI 1020 steel polishing process was performed with Scanning Electron Microscopy (SEM) on a JCM-5000 NeoScope ${ }^{\mathrm{TM}}$. The surface analysis was performed using an Atomic Force Microscope (AFM), NanoSurf's NaioAFM, in contact mode. The roughness measure was obtained with Image Metrology's Scanning Probe Image Processor program in an area of $1.986 \mu \mathrm{m}^{2}$

\section{Results}

\subsection{Roughness and Surface Finish}

Figure 1 shows the AISI 1020 steel rods after the polishing process, using tool bits with and without monolayer HfN coating. The procedure used is indicated in the development of the experiment. In tests with the uncoated tool bit, a continuous chip with a heightened edge was shown to be generated, since the friction between the chip and the tool is high enough so that the chip adapts to the surface of the tool bit.

The presence of this adhering material increases friction and generates self-welding, causing an increase in surface roughness. As for the tests with the coated tool bit, a continuous chip was generated which achieved good surface finish. Once the dissipated energy reduced, it was transmitted to the chip in the interface between it and the cutting tool, thus presenting a low roughness value [27-28].

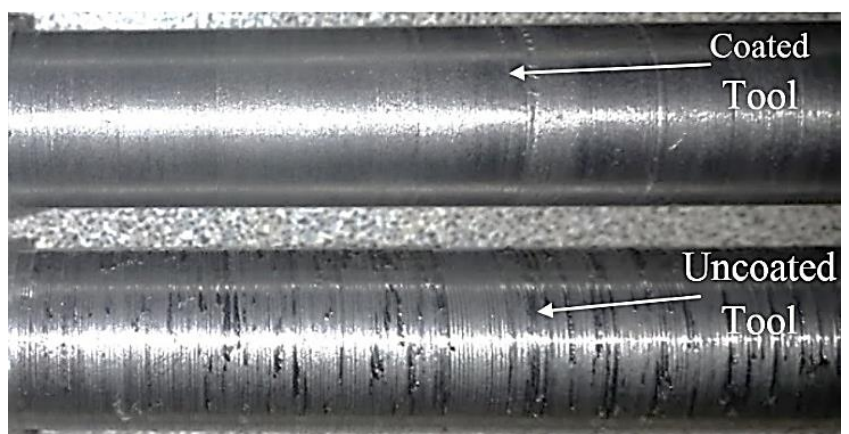

Figure 1 AISI 1020 steel rods obtained by using tool bits with and without monolayer $\mathrm{HfN}$ coating in the polish process.

Table 2 makes evident that by implementing the coated tool, a better surface finish is generated, thus reducing the irregularity of the machining piece.

\subsection{SEM Analysis.}

Figure 2 presents the image obtained in the scanning electron microscope (SEM), thus allowing a comparative analysis of the surface finish obtained with the coated and uncoated tool bits. Figure 2a shows the finishing made by an uncoated tool and the heterogeneity present on the material surface.

Table 2. Parameters of the polishing process using tools with and without HfN coating.

\begin{tabular}{lll}
\hline \multicolumn{1}{c}{ Parameter } & \multicolumn{1}{c}{ First polish } & \multicolumn{1}{c}{ Second polish } \\
\hline Spindle rotation speed & $500 \mathrm{rpm}$ & $1000 \mathrm{rpm}$ \\
Tool feed rate & $0.08 \mathrm{~mm} / \mathrm{rev}$ & $0.01 \mathrm{~mm} / \mathrm{rev}$ \\
Diametrical penetration & $0.25 \mathrm{~mm}$ & $0.10 \mathrm{~mm}$ \\
Tool speed & $40 \mathrm{~mm} / \mathrm{min}$ & $10 \mathrm{~mm} / \mathrm{min}$ \\
\hline
\end{tabular}

Such imperfections are attributed to adhesive wear because the cutting tool reaches a high temperature and the abraded material adheres itself, causing a process that ends with further deterioration because the material is cut by the adhered fragments, and not by the vertex of the tool [29] [30].

In Figure $2 b$, on the other hand, the micrograph shows a surface cut with a tool bit coated in HfN, producing a more constant cut. This indicates that this tool produces a suitable surface finish and less wear on the material to be cut. Considering that the melting point of the hafnium nitride in coating form is high compared to materials such as steel, we can conclude that there is less adhesion of the material to the cutting tool, due to a lower working temperature [31]. This type of characteristic causes lesser wear by friction, since a low percentage of abraded material will adhere to the tool because of its temperature, thus obtaining a better surface finish.

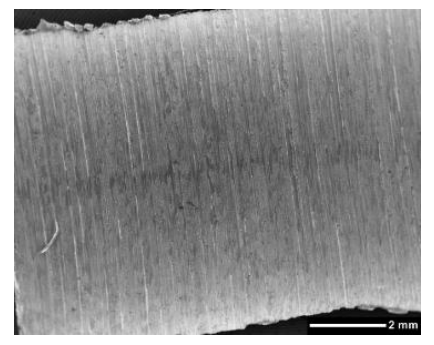

a)

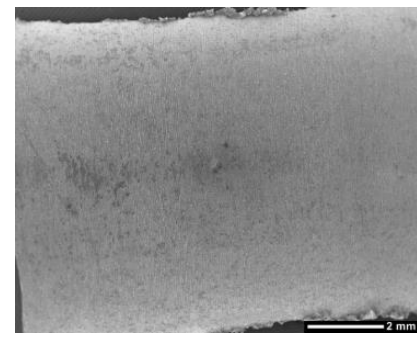

b)
Figure 2 AISI 1020 steel Surface finish visualized on a SEM at a scale of $2 \mathrm{~mm}, a$ ) polished with conventional tool bit, and $b$ ) polished with tool bit coated with $\mathrm{HfN}$.

Figure 3a shows that, upon zooming further onto the analyzed surface, sizable microcracks appear because of the roughing of the uncoated tool. These cracks can become critical when the material is performing the work for which it was manufactured, and this surface imperfections can be the onset of failure of the material. Additionally, having a surface with higher porosity facilitates the appearance of 


\section{TECCIENCLA}

corrosive processes. In comparison, Figure $3 \mathrm{~b}$ shows the surface devastated with the tool bit coated in hafnium nitride. This surface displays areas which are constant and of equal size, less jagged edges and greater symmetry, all factors which are favorable for the resistance of the material and which decrease the likelihood of corrosion in the short run.

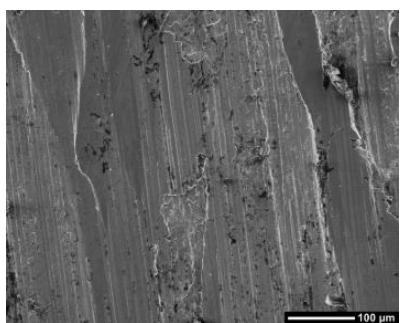

a)

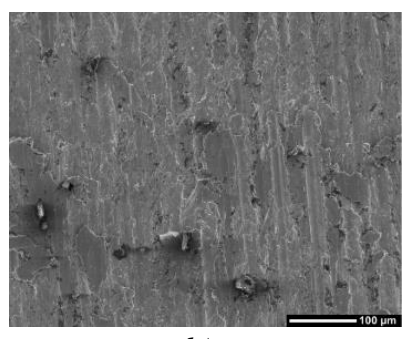

b)
Figure 3 AISI 1020 steel surface finish visualized on a MEB at a scale of $100 \mu \mathrm{m}$, a) polished with conventional tool bit, and b) polished with tool bit coated with HfN.

\subsection{AFM Analysis.}

In the analysis of roughness in function of the cutting tools evaluated under the atomic force microscope (AFM), we performed a comparison of the finish generated by the two types of tools in 7 different areas of $1.986 \mu \mathrm{m}^{2}$. Below, the two zones - with the maximum and minimum values of $R a$ are shown.

Figure 4 displays the area obtained by the uncoated tool bit (4a) compared to the coated tool bit (4b). Image Metrology's SPIP software was used to calculate the roughness $R a$ of each cut. The coated tool showed a lower roughness value: a $R a$ of $891.58 \mathrm{~nm}$ compared to a $R a$ of $1118.9 \mathrm{~nm}$ with the conventional tool. This value indicates a better surface finish suggesting better behavior between the tool and the material when decreasing friction in the tribological pair [32].

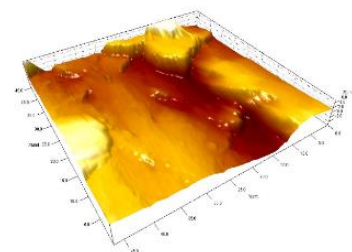

$\mathrm{Ra}=1118.9 \mathrm{~nm}$

a)

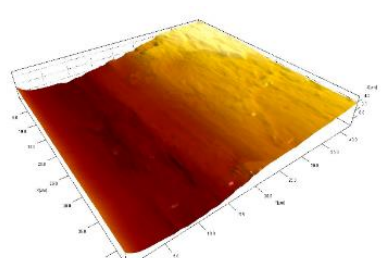

$\mathrm{Ra}=891.58 \mathrm{~nm}$

b)
Figure 4 Surface finish of AISI 1020 steel, visualized en AFM, a) polished with conventional tool bit, and

b) polished with tool bit coated with HfN.
For a more thorough analysis, an area experiencing greater wear from the two tools was selected, that of the uncoated tool bit in Figure $35 a$ and that of the coated tool bit in Figure $35 \mathrm{~b}$. For this second zone of analysis it is necessary to note that although the $R a$ value increases to the maximum value measured for the two trials, the coated tool continues to show a better surface finish, with a roughness value of $\mathrm{Ra}$ $1120 \mathrm{~nm}$ compared to a roughness value of $1696.2 \mathrm{~nm}$ for the uncoated tool, demonstrating the efficiency of the coating. Moreover, Figure 35a reveals an uneven surface, with pronounced peaks and large surface defects, while Figure $35 b$ shows a more homogeneous surface [33].

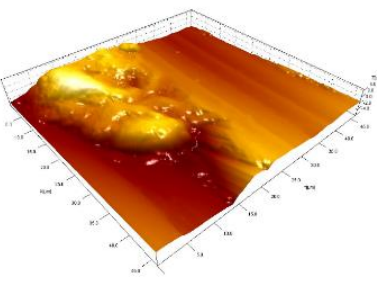

$$
\mathrm{Ra}=1696.2 \mathrm{~nm}
$$

a)

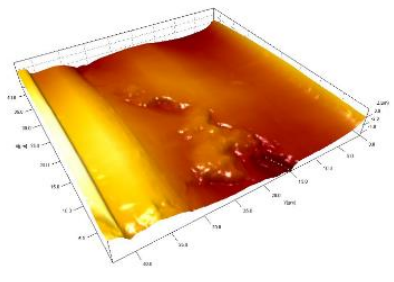

$\mathrm{Ra}=1120 \mathrm{~nm}$

b)
Figure 5 Critical surface finish of AISI 1020 steel, visualized en AFM, $a$ ) polished with conventional tool bit, and $b$ ) polished with tool bit coated with HfN.

This all indicates that applying a monolayer coating of HfN to the cutting tool improves the surface finish of the workpiece. According to Davies et al. [34], this occurs because of a decrease in the rate of temperature variation, improves the quality of the cutting process.

\section{Conclusions}

In summary, the deposition of the HfN monolayer coating onto cutting tool improves the surface finish of the machined piece, demonstrating a homogenization of the produced piece and lower production of surface microcracks, thus avoiding possible early failures.

The use of cutting tools coated with a monolayer of HfN offers several advantages at the industrial level, including increasing the quality of the manufactured product, reducing production time and costs as well as reducing the adhesive wear generated in the tribological pair and its impact.

\section{Acknowledgments}

Product derived from project ING. 1775, financed by "Vicerrectoría de Investigaciónes - UMNG", 2015. 


\section{TECCIENCLA}

\section{References}

[1] F. Halila, C. Czarnota, M. Nouari, A new abrasive wear law for the sticking and sliding contacts when machining metallic alloys, Wear 315 (2014) 125-135.

[2] S. M. Ryan, S. Szyniszewski, S. Ha, R. Xiao, T. D. Nguyen, K. W. Sharp, T. P. Weihs, J. K. Guest, K. J. Hemker, Damping behavior of 3D woven metallic lattice materials, Scripta Materialia 106 (2015) 14.

[3] K. Divakar Rao, D.V. Udupa, C. Prathap, A. Rathod, R.Balasubramaniam, N.K. Sahoo, Optical coherence tomography for shape and radius of curvature measurements of deeply curved machined metallic surfaces: a comparison with two-beam laser interferometry, Optics and Lasers in Engineering 66 (2015) 204-209.

[4] I. D. Hasan, S. M. Kahtan, R. Azmi, M.B. Uday, The influence of the surface roughness on the microstructures and mechanical properties of 6061 aluminium alloy using friction stir welding, Surface and Coatings Technology 270 (2015) 272-283.

[5] N. Mandal, B. Doloi, B. Mondal, Development of flank wear prediction model of Zirconia Toughened Alumina (ZTA) cutting tool using response surface methodology, International Journal of Refractory Metals and Hard Materials 29 (2011) 273-280.

[6] L. J. Xie, X. Ren, M. X. Shen, L. Q. Tu, Parameter correlation of high-temperature creep constitutive equation for RPV metallic materials, Journal of Nuclear Materials 465 (2015) 196-203,

[7] G.R.B.E. Römer, D. Arnaldo Del Cerro, R. Pohl, B. Chang, V Liimatainen, Q. Zhou, A.J. Huis In 't Veld, Picosecond Laser Machining of Metallic and Polymer Substrates for Fluidic Driven Self-Alignment, Physics Procedia 39 (2012) 628-635.

[8] S. P. Murzin, E. V. Shakhmatov, A. A. Igolkin, L. F. Musaakhunova, A Study of Vibration Characteristics and Determination of the Conditions of Nanopores Formation in Metallic Materials During Laser Action, Procedia Engineering 106 (2015) 266-271.

[9] M. Esmaily, N. Mortazavi, M. Shahabi-Navid, J.E. Svensson, L.G. Johansson, M. Halvarsson, On the capability of in-situ exposure in an environmental scanning electron microscope for investigating the atmospheric corrosion of magnesium, Ultramicroscopy 153 (2015) 45-54.

[10] R.H. Basurto, A.I. López-Lorente, M. Valcárcel, Scanning electron microscopy of carbon nanotubes dispersed in ionic liquid: Solvent influence study, Microchemical Journal 122 (2015) 137-143.

[11] M. Teague, B. Gorman, Utilization of dual-column focused ion beam and scanning electron microscope for three dimensional characterization of high burn-up mixed oxide fuel, Progress in Nuclear Energy 72 (2014) 67-71.

[12] E.Y. Guo, M. Y. Wang, T. Jing, N. Chawla, Temperature-dependent mechanical properties of an austenitic-ferritic stainless steel studied by in situ tensile loading in a scanning electron microscope (SEM), Materials Science and Engineering 580 (2013) 159-168.

[13] G. D. Sim, J. H. Park, M. D. Uchic, P. A. Shade, S. B. Lee, J.J. Vlassak, An apparatus for performing microtensile tests at elevated temperatures inside a scanning electron microscope, Acta Materialia 61 (2013) 7500-7510.

[14] Y. Zhang, M. Ding, J. Liu, W. Jia, S. Ren, Studies on bitumen-silica interaction in surfactants and divalent cations solutions by atomic force microscopy, Colloids and Surfaces A: Physicochemical and Engineering Aspects 482 (2015) 241-247.

[15] R. L. Harniman, O.J. Fox, W. Janssen, S. Drijkoningen, K. Haenen, P. W. May, Direct observation of electron emission from grain boundaries in CVD diamond by PeakForce-controlled tunnelling atomic force microscopy, Carbon 94 (2015) 386-395.

[16] Cárdenas, C. et al., Incidence of Corrosion on Electric Power Losses in ACSR Cables, TECCIENCIA, Vol. 11 No. 20, 27-33, 2016

[17] Bernal Castillo, F.; Roa-Rodríguez, G.; Cabrera Cabrera, C; Sierra Melo, N.; Aperador, W.; Determination of the probability and rate of corrosion on reinforced concrete specimens through a remote corrosion monitoring system, TECCIENCIA, Vol. 10 No. 19., 2731, 2015

[18] P. Hovington, M. Dontigny, A. Guerfi, J. Trottier, M. Lagacé, A. Mauger, C.M. Julien, K. Zaghib, In situ Scanning electron microscope study and microstructural evolution of nano silicon anode for high energy Li-ion batteries, Journal of Power Sources 248 (2014) 457-464.

[19] P. Sepulveda-Medina, Y. Katsenovich, V. Musaramthota, M. Lee, B. Lee, R. Dua, L. Lagos, The effect of uranium on bacterial viability and cell surface morphology using atomic force microscopy in the presence of bicarbonate ions, Research in Microbiology 166 (2015) 419-427.

[20] Chiara Musumeci, Andrea Liscio, Vincenzo Palermo, Paolo Samorì, Electronic characterization of supramolecular materials at the nanoscale by Conductive Atomic Force and Kelvin Probe Force microscopies, Materials Today 17 (2014) 504-517.

[21] J.F. Zeng, J.P. Chu, Y.C. Chen, A. Volland, J.J. Blandin, S. Gravier, Y. Yang, On the use of atomic force microscopy for structural mapping of metallic-glass thin films, Intermetallics 44 (2014) 121127.

[22] F. Pöhl, S. Mottyll, R. Skoda, S. Huth, Evaluation of cavitationinduced pressure loads applied to material surfaces by finite-elementassisted pit analysis and numerical investigation of the elasto-plastic deformation of metallic materials, Wear 330-331 (2015) 618-628.

[23] E. Söderlund, P. Ljunggren, Formability and corrosion properties of metal/ceramic multilayer coated strip steels, Surface and Coatings Technology 110 (1998) 94-104.

[24] M. H. Staia, D. G. Bhat, E. S. Puchi-Cabrera, J. Bost, Characterization of chemical vapor deposited $\mathrm{HfN}$ multilayer coatings on cemented carbide cutting tools, Wear 261 (2006) 540-548

[25] C. Escobar, M. Villarreal, J.C. Caicedo, W. Aperador, P. Prieto, Novel performance in physical and corrosion resistance HfN/VN coating system, Surface and Coatings Technology 221 (2013) 182190

[26] S. Ch. Kishore, P. Rao, A. Mahamani, Investigation of Cutting Force, Surface Roughness and Flank Wear in Turning of In-situ A16061-TiC Metal Matrix Composite, Procedia Materials Science 6 (2014) 10401050 .

[27] C.A. Escobar, J.C. Caicedo, W. Aperador, Corrosion resistant surface for vanadium nitride and hafnium nitride layers as function of grain size, Journal of Physics and Chemistry of Solids 75 (2014) 23-30.

[28] M. Szymańska, S. Gierałtowska, Ł. Wachnicki, M. Grobelny, K. Makowska, R. Mroczyński, Effect of reactive magnetron sputtering 


\section{TECCIENCIA}

parameters on structural and electrical properties of hafnium oxide thin films, Applied Surface Science 301 (2014) 28-33.

[29] S.J. Bull, A.M. Jones, Multilayer coatings for improved performance, Surface and Coatings Technology 78 (1996) 173-184.

[30] A. Ravi Shankar, U. Kamachi Mudali, Vipin Chawla, Ramesh Chandra, Magnetron sputter deposition of hafnium nitride coating on high density graphite and niobium substrates, Ceramics International 39 (2013) 5175-5184.

[31] C.A. Escobar, J.C. Caicedo, W. Aperador, Corrosion resistant surface for vanadium nitride and hafnium nitride layers as function of grain size, Journal of Physics and Chemistry of Solids 75 (2014) 23-30.

[32] D. T. Quinto, G. J. Wolfe, P. C. Jindal, High Temperature microhardness of hard coatings produced by physical and chemical vapor deposition, Thin Solid Films 153 (1987) 19-36.

[33] C. Escobar, M. Villarreal, J.C. Caicedo, W. Aperador, H.H. Caicedo, P. Prieto, Diagnostic of corrosion-erosion evolution for [HfNitrides/V-Nitrides]n structures, Thin Solid Films 545 (2013) 194199.

[34] M.A. Davies, T. Ueda, R. M'Saoubi, B. Mullany, A.L. Cooke, On The Measurement of Temperature in Material Removal Processes, CIRP Annals - Manufacturing Technology, Volume 56 (2007) 581604. 